\title{
The Strange Ones: Exploring A Young Adult's Behavior as She Goes Through Rejection and Acceptance of Her Self-Identity
}

\author{
Soewarsono, E.G. \\ English for Creative Industry, Faculty of Letters, Petra Christian University, Siwalankerto 121-131, Surabaya \\ 60236, East Java, INDONESIA \\ Emails: m11414046@john.petra.ac.id
}

\begin{abstract}
This creative work is about a young adult who is excited to explore her identity of someone who has a magical ability. It explores the issue of identities in young adults and its correlation to rebellion in the form of running away, which is common in Indonesia. It aims to bring the readers alongside the main character on her journey of exploring her identity, as well as dealing with her parents' rejection of the identity that she is most comfortable in. To further understand how she deals with her parents' pressure to take an identity she does not like, Erik Erikson's fifth psychosocial stage-Identity vs. Role confusion is used as the first theory of this work. The second theory, James Marcia's identity status, is used to understand how the main character explores her identity in different statuses. The genre of this creative work is low fantasy, which is a subgenre of fantasy that uses minimal magical elements and is set in the real world.

Key words:

Young adult, Self-identity, Identity crisis, Rebellion, Identity exploration, Low fantasy fiction
\end{abstract}

\section{INTRODUCTION}

For a while now, I have been infatuated by fantasy. It is just exciting for me that I could freely bend the logics of this world with the fantasy genre. That is exactly why I want to use this genre for my creative work; precisely, the subgenre of young adult fantasy and low fantasy. First of all, there are many possible definitions for fantasy, but basically fantasy is "literature which contains elements that do not or cannot exist in reality" (Fitzgerald, 2008). It allows writers to create a world that contains elements that is impossible to exist-magic and the supernatural. Fantasy writers are able to freely construct a world with its own rules according to their will and imagination. Specifically, young adult fantasy is a fantasy fiction with young adults as both the protagonists and the target market (Alter, 2015). The young adult fantasy subgenre gives the writer freedom to incorporate many other elements into the story; such as romance, psychology, myth, coming-of-age, and many others that will cater to the young adults. On the other hand, low fantasy is "a subgenre of fantasy that happens in the real world - with the characters discovering hidden supernatural or magical elements" (Alter, 2015). By using the low fantasy genre, I am able to write a story based on the real world instead of making a totally different world. These two subgenres are perfect for my creative work because I want to create a story in an alternate universe of the existing world, set in Indonesia, where magic exists with a young adult as the main character.

Since this creative work needs an elaborate description on how the magical elements work in the world and how the protagonist's experiences build up her character, I decided that the best form to write this work in would be a novel of around 20,000 words. A novel is a visual medium which enables the readers to visualize "imaginary or artistically treated real stories" in their head by reading words (Bonnet, n.d.). By using novel as the form of my creative work, I am able to describe the scenes and feelings of the characters more vividly in the shape of a long prose. As the readers read this creative work, they are able to live in the story as if the events in it can happen in real life. Moreover, I would like to make readers able to go through the moments of my main character's life as if they are there with her and sympathize with her. By sympathizing with the main character of the story, the readers are able to understand the topic that I want to discuss in this creative work: the process of developing a self-identity. 
This creative work will be the first book of a trilogy focusing on the Strange Ones, a special human race which the main character is a part of. I am making it as a trilogy because I feel like the concept of the Strange Ones race can be explored further and one book would not be enough to do that. The first book tells the story of a young girl named Sera, who just finds out that she is a Strange One and tries to find her own identity after the discovery. The second book tells the story after their journey focusing on Eto. Sera is still in the story, but the story is centered on Eto, his background, and his reaching his goals instead. The third book is centered on a new unnamed character that appears on the second book for the first time, who is also a Strange One specializing in healing. In the end, there are three main characters in the series, and Sera's story is the one I am writing for this creative work.

In this creative work, I would like to bring up the topic of self-identity on young adults. I would like to focus on the development of a young adult's identity through the challenges she encounter and the consequence of a third party forcing an identity into the young adult. According to a professor of psychology focusing on Developmental Psychology, Jane Kroger (2017), identity is "the entity that, ideally, enables one to move with purpose and direction in life and with a sense of internal coherence and continuity over time and place." In other words, identity is the sense of self which drives someone forward with a purpose. One has to discover his or her identity by his or herself because pressuring someone else other than self to accept an identity may lead to rebellion (McLeod, 2013).

The purpose of this creative work is to show what kind of experience a young adult has to go through to gain an identity he or she is comfortable with. I also want to show that parents' rejection of their children's identity may lead to a rebellion, in this case, by running away from home. I would like to help young adults understand the importance of discovering their identity by themselves and how the discovery process works. At the same time, I also want to highlight the problem of young adults running away from home because of their parents, which is quite common in Indonesia.

There are two theories that I use in creating this creative work to achieve my purposes. The first is Erik Erikson's theory of psychosocial development, most notably the fifth stage, Identity vs. Role Confusion. Erik Erikson proposed the theory that human beings have eight psychosocial stages in their lives. These stages happen in various age of human lives. From the earliest age to the latest: Trust vs. Mistrust, Autonomy vs. Shame, Initiative vs. Guilt, Industry vs. Inferiority, Identity vs. Role Confusion, Intimacy vs. Isolation, Generativity vs. Stagnation, and Ego Integrity vs. Despair (McLeod, 2013). The fifth stage, Identity vs. Role Confusion, happens during adolescence which is around 12-18 years old. Erikson emphasizes a lot on this period and he considers it to be the most important of all (McLeod, 2013). In this stage, a child has to go through a transition period where they must explore themselves and the role they will have in their adulthood. If the child fails in getting an identity, they will go through role confusion or identity crisis. When they are in this state of crisis, they may try different lifestyles or activities until they get an identity they are most comfortable with. McLeod (2013) mentions that "pressuring someone into an identity can result in rebellion," as one might not be able to agree with the identity he or she is forced into. Forcing someone into an identity may make them feel caged or restricted. This feeling of restriction may lead them to want to break free from the cause of the restriction, which is, for example, the parents. This theory is what I use to justify my main character's action in rebelling against her parents, after they go against her decision of pursuing an identity.

The second theory is James Marcia's identity status. Marcia believes that there are two things that influence identity development in adolescence: crisis and commitment (Marcia, 1980). This means, to have one's own identity, a person has to go through a crisis and holds a commitment to a specific identity. Crisis is a situation in which a person struggle to find his or her identity and commitment means that the person will not suddenly change his or her own identity on a whim. He also thinks that exploration is an important part of the development; as exploration happens when someone wants to find out whether an identity is suitable for oneself or not (Kroger, 2017) whereas if there is little to no exploration, that someone will not fully understand the identity he or she is having. On James Marcia's concept of identity status, he classified identity development into four statuses; identity diffusion, identity foreclosure, moratorium, and identity achievement (Oswalt, 2010). These statuses are in no chronological order and a person can either experience all statuses or only some statuses. By using this theory, I want to show the different phases of identity development 
throughout my creative work as the main character go through a process of active exploration and examination.

With these two theories, I hope to create a novel that is both believable and relatable in terms of exploration of self-identity. 


\section{CONCEPT AND ANALYSIS OF THE CREATIVE WORK}

\subsection{Modes of Expression}

The genre I am using for this creative work is the subgenre of fantasy, which is low fantasy. I chose this genre because I want to make a story that is relatable for my young adult readers even if it has fantasy elements in it. The story of a low fantasy novel is set in the real world or a world that is very similar to the world we live in. Instead of the world being enveloped with magic, the world in low fantasy genre only has few people or certain groups possessing magical elements. It contrasts with the high fantasy genre, which is set in a totally different world filled with magic elements and creatures and has large-scale quests (Alter, 2015). Low fantasy stories do not focus on the 'good versus bad' plot like high fantasy, but rather on conflicts that happen in daily life. I chose the low fantasy genre in the hope that my creative work will be relatable to the Indonesian young adult readers.

In creating my creative work, I was mostly inspired by Rick Riordan's writing style. I have read and loved Percy Jackson and the Olympians series (2005-2009) written by Riordan himself and have been influenced by the way he conveyed his stories. In a review by Chris Meadows, a writer and editor of TeleRead (2017), he mentioned that Rick Riordan has "modernized mythology" in the Percy Jackson series. Riordan describes unimaginable or uncommon things by using words that people use daily in this modern world so it would help his readers to imagine easier. For example, he compared throwing a shield to a game of football. His writing style is straightforward and light for a fantasy novel, yet still very descriptive in its own way. I am using this style since I find it to be very comfortable and fun to work with. Moreover, I want my young adult readers to be able to read my fantasy novel without having to re-read multiple times just to understand one part of my story.

Unlike Rick Riordan's works, my creative work strikes closer to the Indonesian young adult readers. They will be able to react to and sympathize with my characters better, because they are also Indonesian. My creative work is also based on a different fantasy element compared to Riordan's works which are mythology-based. My novel uses the legend of fairies as its main base and has no existence of monsters and other fantasy elements. Without these elements, the readers will have an easier time incorporating themselves into the story.

In the creative work, the point of view I use is the third-person limited point of view. It uses third-person pronouns like he, she, or they but can only follow one character's life, thought, and feelings in contrast to third-person omniscient which is able to know all characters' thoughts (Wiehardt, 2017). I use this point of view because I think using the third-person point of view will give me freedom to describe the setting of this alternate universe rather than a first-person point of view. I prefer to use limited point of view rather than omniscient point of view because I feel that it will make the story more consistent if I focus on just one character.

\subsubsection{Genre codes and conventions}

In this section, I am talking about the genre codes and conventions of the low fantasy genre. I have written the characteristics of the genre in table below, taken from an article by an author named Marsha A. Moore in her website Fantasy Faction (2014) and an article in the website Stratton Press (2017).

Table 2.1 Table of Genre Codes and Convention of Low Fantasy

\begin{tabular}{|c|c|c|}
\hline Story Elements & $\begin{array}{lll}\text { Conventions } & \text { of } & \text { Low } \\
\text { Fantasy } & & \\
\end{array}$ & Conventions of my Creative Work \\
\hline Setting & $\begin{array}{l}\text { Set in the primary, "real" } \\
\text { world, or a rational and } \\
\text { familiar fictional world, } \\
\text { with the inclusion of } \\
\text { magical elements. }\end{array}$ & $\begin{array}{l}\text { My creative work is set in Indonesia } \\
\text { in the modern } 21^{\text {st }} \text { century. }\end{array}$ \\
\hline Theme & $\begin{array}{l}\text { Center on the concept of the } \\
\text { underdog, which means } \\
\text { someone who is } \\
\text { underestimated. The device } \\
\text { of magic allows the author }\end{array}$ & $\begin{array}{l}\text { The main character in my story is a } \\
\text { teenager, which is usually side-eyed } \\
\text { by the society (the underdog) and in } \\
\text { the case of my story, by her parents. } \\
\text { My story sees how the discovery and } \\
\text { usage of magic within the main }\end{array}$ \\
\hline
\end{tabular}




\begin{tabular}{|l|l|l|}
\hline Fantasy Elements & $\begin{array}{l}\text { greater agency than } \\
\text { expected in the real world. }\end{array}$ & $\begin{array}{l}\text { character, on top of her experiences } \\
\text { throughout the story, will help her to } \\
\text { explore her self-identity. }\end{array}$ \\
\hline $\begin{array}{l}\text { Low appearance of } \\
\text { traditional fantasy elements } \\
\text { within the story there is } \\
\text { just enough fantasy } \\
\text { elements to make the line } \\
\text { between reality and fantasy } \\
\text { blurred, creating a sense of } \\
\text { ambiguity. }\end{array}$ & $\begin{array}{l}\text { Magic is believed to be nonexistent } \\
\text { in my story's world, much like the } \\
\text { real world. However, turns out that } \\
\text { magic exists in the world and it is } \\
\text { just hidden from the public's eyes. }\end{array}$ \\
\hline Characters & $\begin{array}{l}\text { Characters are marginalized } \\
\text { by the society. Only one } \\
\text { character or a few have } \\
\text { magical abilities. }\end{array}$ & $\begin{array}{l}\text { The main character of my story, } \\
\text { Sera, is a teenager. Teenagers are } \\
\text { underestimated by the society } \\
\text { because of their young age and lack } \\
\text { of experience. She is also a part of a } \\
\text { special human race, the only people } \\
\text { who have magical abilities in my } \\
\text { story's world. }\end{array}$ \\
\hline
\end{tabular}

\subsection{Outline of the Creative Work}

\subsubsection{Theme}

The existence of a theme in a story is very important, as it is in my creative work. In my creative work, the subject matter that drives my story forward is self-identity and the theme is how trials lead to the exploration of self-identity. In this novel, my characters have to go on a journey to retrieve a treasure. There are stacks of challenges that my characters face while trying to retrieve the treasure - such as facing and getting chased around by bad guys, having to choose between priorities, facing their own fears and insecurities - which ultimately will lead the main character to explore her self-identity as a Strange One. She will realize her own shortcomings and strength and finds a way to use them to her advantage.

\subsubsection{Plot}

Sera is a girl who just finished her high school and is in her break before college starts in three months. Unlike normal people, however, she can see the future and she has a pair of pink eyes. She goes to a mall and meets a weird guy with his hair dyed blue, Eto. Together, they successfully stop a suicide bomber from detonating the bomb inside the mall and both of them introduce themselves to each other. Through Eto, Sera finds out that she is a Strange One. He also says that he needs her help. He tells her to ask her family if she wants to get more information. Eto gives her his phone number to keep in contact before they separate. When she gets home, she asks her father who finally admits that they are a special race of human. Their official name is Seltsam-German for strange - but they are commonly called the Strange Ones due to their strange nature and mysterious origins. Then, Sera contacts Eto who finally tells her that he needs her help in locating a treasure called the Blue Rose. He promises Sera anything in exchange for her help. Sera then agrees to help, but she needs to ask for their parents' permission first. However, when she asks, her parents express a strong disapproval. They do not want her to have anything to do with the Strange Ones because of a past event. They did not even tell Sera of their extended family, which is composed of all The Strange Ones, because they fear that Sera might get in danger. Sera, feeling like her parents kept on restricting her from doing what she wants, finally goes to the extreme and runs away from home anyway.

Sera leaves to Eto's place the next day to discuss about their strategy on finding the Blue Rose. In another place, a man named Andrew also wants to get his hands on the Blue Rose to satisfy his own needs. He asks for someone else to help him capture Sera and Eto, so he can get the Blue Rose. Sera feels useless when she could not help Eto in their search. She confides in Eto with her worries and he tells her to do whatever she thinks is best. Sera contacts her parents and they apologize to each other and promise to treat each other better. The next day, when she arrives home, she could 
not find her parents anywhere. It turns out that they were kidnapped by Andrew and he threatens her to go to him or he will hurt her parents.

She sends a vague message to Eto and goes to Andrew's house after, where she reunites with her parents and reconciles with them. There, Andrew teaches her how to use her powers efficiently. However, right before she could tell him the place of the Blue Rose, Eto comes and rescues her and her family. Eto and Sera's family then conspire to get the Blue Rose before Andrew can. They trap Andrew's men to go to another place, but Andrew outsmarts them and comes to the real place. Andrew tries to lure Sera into giving him the treasure, but Sera refuses and Andrew resorts to threatening. Sera gives him the Blue Rose in the end and he goes away. As he goes farther and farther, however, the treasure turns out to be fake.

Meanwhile, Eto and Sera already ran away from the monument with the real Blue Rose. Sera's parents then introduce her to their extended family, making Sera feel accepted in the Strange Ones community. The story ends with Eto asking Sera for another help.

\subsubsection{Characters \\ - Major characters \\ - Serafina Tanaya}

Age: 18 years old

Serafina, usually called Sera, is the quiet girl among her peers. She is an introvert who does not mind spending her time with other people as long as she gets her time alone when she needs it. She is just a regular girl anyone can find anywhere, but she is actually covering up the fact that she has pink eyes. She does not know why she had to hide them since having pink eyes was the norm for her and her family, but she hides her eyes anyway because her parents told her to. She has a personality that does not question things just because it is too much of a hassle for her. She is also the type to avoid troublesome things like being too involved in another person's problem. She can do anything she gets her hands on, which is the reason why she gets bored very easily. In other words, she is a jack-of-all-trades, but master of none. She has good scores in mathematics and science, and with her teacher and parents' recommendation, she applies herself to the medical department in a renowned public university in Surabaya. Her parents made her do lots of things she is not interested in, but she does them anyway. Deep down, she feels frustrated that she could not defy her parents even if she wanted to. Even though her life is already set with no problems, she sometimes feels curious of what it would feel like to have more excitement in her life. She can be a bit stubborn once she sets her eyes on something. She cares about her family very much, though at the beginning her pride is more important than her family's feelings. Her hobby includes reading and lazing around in her room. She prefers to stay home, but she would not hesitate to go out if one of her friends invited her to go. What she dislikes the most is when someone interrupts her when she is talking and a lot of people say she is quite scary when she gets angry. As a Strange One, she can see the future, although only bits of it as if she is watching a movie. At first, she did not know the way to trigger her to see the future. Usually it comes by randomly when she sees an object (dead or alive) to see its future or a big event that involves her happens. In the end, she finally finds out that the way to control her power is by keeping her eyes open and concentrating on one object.

\section{- Eto Nafarin}

Age: 19 years old

Eto is a guy one year older than Sera who suddenly appeared in front of her when they were both in the same mall. He has a natural sky blue hair. He has an outgoing personality and he can befriend other people quickly. He is using the cheerful front to hide the fact that he feels lost and scared because he woke up one day with his memories of the last two years lost. At times, he can be seen looking sad but turns cheerful a moment later. He is actually from Banjarmasin, but is staying in Surabaya because he was told by a mysterious person that he might find a clue to find Blue Rose there. He wants to get the Blue Rose to get his memories back. He does not remember at the beginning of the story, but his family is the Keeper of the Blue Rose. His family — his dad, mom, and older sister - are missing. He is descended from the Saranjana people from the magical city of Saranjana in South Kalimantan. As a Strange 
One, he can control or manipulate anything as long as he knows it exists-except humans. The most he could do to humans is manipulate their senses (illusions). The way to trigger his power is by citing words in his head.

- Supporting characters

- Shalom Harrison

Age: 19 years old

An ordinary human. Shalom is Eto's high school friend who lost contact with the latter before they met again in Surabaya, where Shalom is attending university at. He is from a rich Dayak family in Banjarmasin, but lives alone in Surabaya in a house his parents provided along with a housekeeper. His family and Eto's family are close, and for generations his family had been serving and aiding Eto's family. His ancestors thought Eto's ancestors were the personification of gods and that it is their duty as the natives of Banjarmasin to make them feel welcomed. The book about the Strange Ones, $W e$, They, $U s$, which appears in the story was written by his ancestor. Since child, he has been well-versed in the matters of the Strange Ones. Despite being rich, he is humble and gentle to anyone. He is upright but he blends well with his surroundings. He is the type of person who would not be able to ignore an abandoned animal. Nevertheless, he is strict when he needs to, usually with Eto. Eto is currently staying at his house in Surabaya.

\section{- Andrew Hendrawan}

Age: 32 years old

Andrew is a young businessman who got the position General Manager of a conglomerate by marrying into his wife's family, the owner of the company. To other people, he is kind and well-mannered. He hides his charismatic and ambitious side from the public. He is able to manipulate people just by his words. He is usually nice when talking but if someone is acting foolish in front of him, he can be quite sarcastic. Even though he is married, he and his wife usually live apart. He found out about the Strange Ones and the Blue Rose because he befriended a Strange One when he studied abroad in Germany. He researched about them himself and got his hands on a book called We, They, Us which is a book on the Strange Ones. As his wife's family had built a big library decades ago, Andrew donated the book he got into the library in hopes of luring a Strange One so he can find the Blue Rose. Andrew wants to get his hands on the Blue Rose because he wants to wake his younger sister up from a comatose. He is an ordinary human and the villain of this novel.

- Teddy Tanaya

Age: 45 years old

Sera's father and a director in a manufacturing company. Teddy is a Strange One who also has the same pink eyes as Sera. He does not, however, have the same foreseeing ability as her. His power allows him to see through a lie. When someone lies, he sees his or her body with no color. As a result of his power, he becomes a strict man who does not tolerate lying. He and his wife never tells Sera of their origins or their family because they do not want her to mingle with the Strange Ones. He is protective towards his family and would not hesitate to sacrifice himself to save his family. He might look tough, but he has a soft spot for his wife, Annisa. Usually, his eyes would be covered by contact lenses. He was born and raised in Bali, and his and his wife's relatives all live there.

- Annisa Sofia Limanto

Age: 45 years old

Sera's work-at-home mother. Annisa is a famous book reviewer who goes under the pseudonym 'Kaila'. She married her fifth cousin, Teddy, and gave birth to Sera. She is an enthusiastic woman and the only extrovert in the house. She loves her small family very much to the extent of cutting off all ties with her other relatives in fear that they will endanger her daughter's life. She is nice and bubbly, but is also stubborn just like her daughter. She is also a Strange One and her ability allows her to have a high affinity with all kinds of weapons, meaning she can use any kind of weapon like an expert. Unlike her husband and daughter, she does not have pink eyes. Instead, she has heterochromia; yellow in her left eye and green in her right eye. Usually, she would cover them with lenses like the rest of her family.

- Luna Nafarin 
Age: 21 years old

Eto's missing older sister. Luna is charming and charismatic. She was always kind to other people, but in reality she feels no bond with anyone, even her family. In fact, even though she says she cares for her brother a lot, she feels joy in seeing him struggle. She has psychopathic and sadistic personality disorder tendencies. She was the one who stole the Blue Rose from her family and fled with it, all because she felt like it was the reason her parents never paid attention to her. She is the antagonist for the whole trilogy and the one who orchestrated everything in this novel. As a Strange One, she has aqua green hair and the power to control dreams and their dreamers. People who do not know her and only meet her through their dreams thought that their dreams were prophetic, and thus doing anything to do whatever she told them to in their dreams since they thought she was something like a god.

\subsubsection{Conflict}

The conflict that happens in my creative work takes the form of Man versus Self, which is a conflict that happens within the characters themselves. In the middle of my creative work, Sera starts to have doubts within herself and start to question herself before she finally reaches a point of realization at the end. There is also a Man versus Man conflict - a conflict that happens between a character and another character or characters - as Sera rebels against her parents' rejection, and then when Sera and Eto have to go against Andrew to get the Blue Rose, the treasure they are all searching for. The Man versus Self conflict is more dominant in the story because I want to focus on Sera's character development within herself.

\section{CONCLUSION}

The main purpose I have in making this creative work is to show the importance of selfidentity exploration in young adults and support from others in exploring said self-identity. I hope this purpose will be able to make the readers be more aware that having a crisis while exploring one's identity is perfectly fine and it should not be a sign of failure. Also, forcing an identity to someone might make him or her rebel, with one example being running away from home. In that case, the best thing to do is to talk it out calmly and to reach a point of understanding from both sides.

Writing this novel has been a very valuable experience for me. It is the first time I have ever completed a full-length novel and I learned a lot from it. I figured out that I need to work on my time management better since I am prone to procrastinating. I was so close to not making it to the deadline just because I procrastinated. I also felt the importance of research and finding an issue to bring up in my novel. I struggled for weeks trying to find the perfect issue that I could address in my novel before finally settling on the problem of teenagers running away from home. I also had to deal with a writer's block so close to the deadline, but thankfully I managed to get out of it and finished my creative work on time. At the end of it all, I learned how to write a full length novel in a few months and actually did it. I will be sure to keep it in my mind and remember how it felt if I make another novel in the future.

I plan to continue revising my novel, and when I feel that it is good enough, try sending it to a local publisher. I am also going to write the second and third book of the trilogy, which are the sequels of this novel. I want to keep writing even in the future, whether it is in the form of novel or something else. Hopefully, I can get published one way or another because I really want to be able to show my stories to the whole world someday.

\section{REFERENCES}

Alter, N. (2015). 17 common fantasy sub-genres. Retrieved August 25, 2017, from https://thoughtsonfantasy.com/2015/12/07/17-common-fantasy-sub-genres/

Bonnet, J. (n.d.) Writing screenplays vs. novels: A tough love guide for writers. Retrieved April 4, 2018, from https://www.writersstore.com/the-novel-vs-the-screenplay-a-tough-love-guidefor-talented-writers

Fitzgerald, M. A. (2008). Young adult fantasy fiction in recent years: A selective annotated bibliography. 
Kroger, J. (2017). Identity development in adolescence and adulthood. Retrieved March 12, 2018, from http://psychology.oxfordre.com/view/10.1093/acrefore/9780190236557.001.0001/acrefore9780190236557-e-54

Marcia, J. E. (1980). Identity in adolescence. Handbook of adolescent psychology, 9(11), 159-187.

Meadows, C. (2017). Review: Rick Riordan's 'Percy Jackson' books. Retrieved April 4, 2018, from https://teleread.org/2017/04/13/review-rick-riordans-percy-jackson-books/

McLeod, S. A. (2013). Erik Erikson. Retrieved March 12, 2018, from www.simplypsychology.org/Erik-Erikson.html

Moore, M. A. (2014). Survey of fantasy subgenres - Part one: High and low fantasy. Retrieved September 26, 2017, from http://fantasy-faction.com/2014/survey-of-fantasy-subgenres

Oswalt, A. (2010). James Marcia and self-identity. Retrieved September 3, 2017, from https://www.mentalhelp.net/articles/james-marcia-and-self-identity/

Stratton Press. (2017). Distinguishing between the subgenres of high and low fantasy. Retrieved September 26, 2017, from https://stratton-press.com/subgenres-of-high-and-low-fantasy/

Wiehardt, G. (2017). Third-person point of view: Omniscient or limited. Retrieved April 4, 2018, from https://www.thebalance.com/third-person-point-of-view-1277092 